\title{
Pengembangan Perangkat Pembelajaran IPA Berbasis Guided Inquiry
}

\author{
Nur'aini Nur'aini \\ Pendidikan Kimia, Universitas Negeri Makassar \\ Email: yunusnuraini14@gmail.com \\ Muhammad Danial \\ Pendidikan Kimia, Universitas Negeri Makassar \\ Email: muh_niels@yahoo.com

\section{Sugiarti Sugiarti} \\ Pendidikan Kimia, Universitas Negeri Makassar \\ Email: atisugiarti34@yahoo.co.id
}

(Diterima: 15-Desember-2019; direvisi: 16-Januari-2020; dipublikasikan: 15-Maret-2020)

\begin{abstract}
Abstrak: Penelitian ini merupakan penelitian pengembangan yang bertujuan untuk menghasilkan perangkat pembelajaran IPA berbasis guided inquiry pada pokok bahasan energi dalam sistem kehidupan yang valid, praktis, dan efektif. Untuk mengetahui tingkat kevalidan, kepraktisan, dan keefektifan perangkat pembelajaran IPA berbasis guided inquiry pada pokok bahasan energi dalam sistem kehidupan yang dikembangkan. Pengembangan Perangkat Pembelajaran menggunakan model dari Thiagarajan (Four-D) yang terdiri atas empat tahap, yaitu define, design, develop, dan dessiminate. Uji coba Perangkat Pembelajaran dilaksanakan pada peserta didik kelas VII.1 SMP Negeri 36 Makassar tahun pelajaran 2018/2019. Pengumpulan data menggunakan lembar observasi dan angket, selanjutnya data dianalisis dengan teknik analisis deskriptif. Produk yang dihasilkan dalam penelitian ini adalah Perangkat pembelajaran yang mencakup rencana pelaksanaan pembelajaran (RPP), lembar kerja peserta didik (LKPD), dan bahan ajar peserta didik (BAPD). Hasil validasi terhadap perangkat pembelajaran yang dikembangkan diperoleh rata-rata penilaian validator memenuhi kriteria valid dan keseluruhan komponennya dinilai reliabel. Hasil penilaian kepraktisan terhadap perangkat pembelajaran yang dikembangkan menunjukkan bahwa terdapat kekonsistenan antara hasil penilaian persepsi ahli dengan hasil pengamatan observer, yaitu sama-sama memberikan hasil penilaian kriteria tinggi atau baik. Dan efektif untuk digunakan karena terdapat kekonsistenan antara hasil penilaian persepsi ahli dengan hasil pengamatan observer. Hasil penilaian persepsi ahli yaitu memberikan hasil penilaian keefektifan dengan kriteria tinggi atau baik. Serta hasil pengamatan observer terhadap empat indikator kriteria keefektifan semuanya terpenuhi.
\end{abstract}

Kata kunci: Pengembangan Perangkat Pembelajaran; Guided Inquiry; Energi dalam Sistem Kehidupan.

Abstract: This study is development research, which aims at producing guided inquiry-based IPA (Natural Sciences) learning tools in energy and life system subject which is valid, practical, and effective, discovering the level of validity, practicality, and effectiveness of guided inquiry-based IPA learning tools in energy and life system subject developed. The development of learning tools employed Thiagarajan (Four-D) model which consists of four stages, namely defining, design, development, and dissemination. The test of learning tools was conducted to the students of grade VII.1 at SMPN 36 Makassar of academic year 2018/2019. Data collecting employed observation sheet and questionnaire. The data were then 
analyzed by using descriptive analysis technique. The products produce in this study are the lesson plan (RPP), student's worksheet (LKPD), and student's textbook (BAPD). The results of the validation on the learning tools developed, it is obtained the mean score based on the assessors which met the valid criteria and all of the components of learning tools are valued as reliable. The result of the field test on the practicality of learning tools developed shows that there is consistency between the result of experts' perceptions and observers', which is both gave high criteria or good. The learning tools are also effective to be applied because the result of the field test indicates that there is consistency between the result of experts' perceptions and observers'. The result of experts perceptions gave the effectiveness result with high criteria or good. The result of observation on four indicators of effective criteria were all met.

Keywords: Learning Materials Development; Guided Inquiry; The Energy Of The Life System.

\section{PENDAHULUAN}

Indonesia sebagai bangsa dan negara akan terus menjalani sejarahnya. Ibarat sebuah organisme negara Indonesia lahir, tumbuh, berkembang, dan mempertahankan kehidupannya untuk mencapai apa yang dicita-citakan di awal kelahirannya. Cita-cita luhur tersebut tercantum secara jelas dalam Pembukaan UUD 1945 alinea keempat, yakni melindungi segenap bangsa dan seluruh tumpah darah Indonesia, memajukan kesejahteraan umum, mencerdaskan kehidupan bangsa dan ikut melaksanakan ketertiban dunia berdasarkan kemerdekaan, perdamaian abadi dan keadilan sosial. Sungguh sangat luhur dan humanis cita-cita luhur bangsa dan negara Indonesia tersebut. Sepatutnya kita harus berkontribusi sesuai dengan peran kita untuk mewujudkan citacita luhur bangsa dan negara Indonesia.

Salah satu cara dan strategi untuk mempercepat terwujudnya cita-cita negara kita adalah dengan mempersiapkan generasi masa depan yang tangguh, cerdas, mandiri, dan berpegang teguh pada nilai-nilai spiritual. Mereka harus dipersiapkan sedemikian rupa dalam suatu lingkungan yang kondusif. Salah satu lingkungan yang sangat ideal untuk hal tersebut adalah institusi pendidikan mulai dari prasekolah, tingkat dasar, tingkat menengah, hingga jenjang perguruan tinggi.

Dalam rangka mewujudkan kondisi tersebut di atas, pemerintah melalui Departemen Pendidikan dan Kebudayaan terus melakukan pembaharuan dan inovasi dalam bidang pendidikan, salah satunya adalah pembaharuan dan inovasi kurikulum, yakni lahirnya kurikulum 2013 sebagai penyempurnaan kurikulum 2006. Tujuan kurikulum 2013 dalam Kunandar (2014) adalah untuk mempersiapkan manusia Indonesia agar memiliki kemampuan hidup sebagai pribadi dan warga negara yang beriman, produktif, kreatif, inovatif, dan efektif serta mampu berkontribusi pada kehidupan bermasyarakat, berbangsa, bernegara, dan peradaban dunia.

Pembelajaran Ilmu Pengetahuan Alam (IPA) di Sekolah Menengah Pertama (SMP) pada kurikulum tahun 2013 berdasarkan Permendikbud Nomor 24 tentang Kompetensi Inti dan Kompetensi Dasar (2016) terdapat beberapa perubahan diantaranya adalah konsep pembelajarannya dikembangkan sebagai mata pelajaran integrated science atau IPA terpadu bukan sebagai pendidikan disiplin ilmu. Konsep keterpaduan ini ditunjukkan dalam Kompetensi Inti (KI) dan Kompetensi Dasar (KD) pembelajaran IPA yakni di dalam satu KD sudah memadukan konsep-konsep IPA dari bidang ilmu biologi, fisika, kimia, dan ilmu pengetahuan bumi dan antariksa (IPBA).

Konsep pembelajaran IPA dalam pelaksanaannya mengacu pada Permendikbud Nomor 22 tentang Standar Proses Pendidikan Dasar dan Menengah (2016) bahwa pembelajaran IPA harus dapat 
menumbuhkembangkan kompetensi peserta didik pada ranah sikap (afektif), pengetahuan (kognitif), dan keterampilan (psikomotor). Ketiga ranah kompetensi tersebut memiliki lintasan perolehan (proses psikologis) yang berbeda. Sikap diperoleh melalui aktivitas menerima, menjalankan, menghargai, menghayati, dan mengamalkan. Pengetahuan diperoleh melalui aktivitas mengetahui, memahami, menerapkan, menganalisis, mengevaluasi, dan mencipta. Keterampilan diperoleh melalui aktivitas mengamati, menanya, mencoba, menalar, menyaji, dan mencipta.

Salah satu pendekatan yang disarankan oleh kurikulum 2013 adalah pendekatan saintifik (ilmiah) yang berkaitan erat dengan metode saintifik. Metode saintifik (ilmiah) pada umumnya melibatkan kegiatan pengamatan atau observasi yang dibutuhkan untuk perumusan hipotesis atau mengumpulkan data serta dilandasi oleh pemaparan data yang diperoleh melalui pengamatan atau percobaan. Oleh sebab itu, kegiatan percobaan dapat diganti dengan kegiatan memperoleh informasi dari berbagai sumber atau observasi. "Pembelajaran dengan integrasi kegiatan ilmiah pada umumnya merupakan kegiatan inkuiri" (Sani, 2015).

Proses belajar mengajar yang baik harus didahului dengan persiapan yang baik pula, tanpa persiapan yang baik sulit rasanya menghasilkan pembelajaran yang baik di kelas. Oleh karena itu, sudah seharusnya guru sebelum melaksanakan proses pembelajaran harus menyusun terlebih dahulu perencanaan atau perangkat pembelajaran. Perangkat pembelajaran yang disusun merupakan satu kesatuan yang tak terpisahkan dan sinkron satu sama lain agar hasilnya lebih optimal. Penyusunan perangkat pembelajaran tersebut antara lain meliputi Rencana Pelaksanaan Pembelajaran (RPP), Lembar Kerja Peserta Didik (LKPD), dan Bahan Ajar Peserta Didik (BAPD).

Berdasarkan pengamatan penulis sebagai guru IPA SMPN 36 Makassar tentang kegiatan pembelajaran IPA di sekolah tersebut bahwa Rencana
Pelaksanaan Pembelajaran (RPP) sebagai salah satu unsur perangkat pembelajaran yang disusun oleh guru telah menggunakan model pembelajaran yang disarankan pada kurikulum 2013, yaitu discovery learning. Akan tetapi, RPP tersebut belum sinkron dengan bahan ajar dan LKPD yang digunakan, sehingga dalam pelaksanaannya masih saja kurang optimal hasilnya.

Selain itu, Lembar Kerja Peserta Didik (LKPD) yang juga merupakan salah satu unsur perangkat pembelajaran ditemukan bahwa guru masih menggunakan Lembar Kerja Peserta Didik (LKPD) yang ada pada buku paket peserta didik dengan cara memperbanyak lembaran tersebut setiap kali tatap muka atau menginstruksikan secara langsung kepada peserta didik untuk melihat pada buku paket IPA yang dibagikan saat proses pembelajaran berlangsung. Sehingga Lembar Kerja Peserta Didik (LKPD) yang digunakan tentunya kurang menarik perhatian peserta didik untuk mempelajarinya karena hanya berupa lembaran fotocopian dan tentunya kurang sinkron dengan Bahan Ajar dan Rencana Pelaksanaan Pembelajaran (RPP) yang digunakan. Padahal Lembar Kerja Peserta Didik (LKPD) bermanfaat dalam meningkatkan aktivitas peserta didik dalam proses pembelajaran, membantu guru dalam mengarahkan peserta didik menemukan konsep-konsep melalui aktivitasnya, mengembangkan keterampilan proses, mengembangkan sikap ilmiah, dan membangkitkan minat peserta didik dalam mengikuti pembelajaran.

Unsur perangkat pembelajaran lainnya adalah Bahan Ajar Peserta Didik (BAPD) masih sebatas menggunakan buku paket yang disiapkan oleh pihak sekolah. Buku paket tersebut hanya bisa dipergunakan oleh peserta didik pada saat proses pembelajaran berlangsung. Selain itu, buku paket yang digunakan sebagai bahan ajar tentunya kurang sinkron dengan Lembar Kerja Peserta Didik (LKPD) dan Rencana Pelaksanaan Pembelajaran (RPP) yang digunakan dalam proses pembelajaran karena dirancang dan disusun oleh orang 
yang berbeda. Sebagai akibat dari kondisi tersebut di atas, ditemukan bahwa peserta didik pada SMP Negeri 36 Makassar masih kurang terhadap pemahaman dan penguasaan konsep-konsep dasar IPA utamanya pada pokok bahasan Energi dalam Sistem Kehidupan. Hal ini terlihat dari motivasi belajar peserta didik masih kurang, aktivitas bertanya dan menjawab peserta didik pada saat interaksi dalam pembelajaran masih kurang, dan masih adanya peserta didik mengerjakan hal-hal selain aktivitas pembelajaran yang tidak seharusnya dilakukan.

Rendahnya pemahaman dan penguasaan konsep-konsep dasar IPA peserta didik pada SMP Negeri 36 Makassar menunjukkan rendahnya kinerja ilmiah dan sekaligus mencerminkan rendahnya motivasi peserta didik tersebut untuk belajar IPA. Padahal dengan meningkatkan kinerja ilmiah peserta didik melalui kegiatan pembelajaran mampu meningkatkan keterampilan proses dan sikap ilmiah yang dimilikinya, yang nantinya akan bermuara pada terciptanya konsep jangka panjang pada memori peserta didik. Dengan demikian, peserta didik tentu akan mampu membangun pengetahuannya sendiri, dan akhirnya akan bermuara pada peningkatan hasil belajarnya.

Berdasarkan fakta tersebut di atas, maka dipandang perlu adanya suatu perangkat pembelajaran IPA mencakup Rencana Pelaksanaan Pembelajaran (RPP), Lembar Kerja Peserta Didik (LKPD), dan Bahan Ajar Peserta Didik (BAPD) yang tepat dan sinkron satu sama lain khususnya pada pokok bahasan Energi dalam Sistem Kehidupan, untuk memenuhi kebutuhan peserta didik dalam memahami dan menguasai konsep serta untuk memudahkan guru dalam mengajarkan konsep-konsep dasar IPA.

Berdasarkan hasil penelitian Suduc et al. (2015) bahwa strategi pembelajaran inkuiri dapat dilaksanakan mulai dari Sekolah Dasar, karena terbukti dapat menstimulasi motivasi peserta didik, penerapan keterampilan riset peserta didik, konstruksi makna dan perolehan pengetahuan ilmiah. Pada penelitian ini, penulis memilih salah satu bentuk inquiry untuk diterapkan dalam pengembangan perangkat pembelajaran IPA yaitu guided inquiry (inkuiri terbimbing). Guided inquiry penulis pilih karena menyediakan lebih banyak arahan bagi peserta didik, utamanya yang belum siap untuk menyelesaikan masalah, sehingga cocok diterapkan bagi peserta didik kelas VII SMP yang masih membutuhkan arahan guru dalam menyelesaikan masalah. Adapun beberapa hasil penelitian tentang model pembelajaran guided inquiry yaitu hasil penelitian Susanti (2016) menunjukkan bahwa perangkat pembelajaran IPA model inkuiri terbimbing efektif untuk melatihkan keterampilan proses sains peserta didik, hasil penelitian Sudiarman (2015) menunjukkan bahwa perangkat pembelajaran fisika berbasis inkuiri terbimbing praktis dan efektif untuk digunakan dalam proses belajar mengajar serta dapat melatihkan keterampilan proses sains kepada peserta didik SMP, hasil penelitian Sulistyawan (2015) menunjukkan bahwa pembelajaran berbasis inkuiri terbimbing dapat menumbuhkan minat belajar peserta didik serta dapat meningkatkan ketuntasan hasil belajar peserta didik.

Hasil penelitian Margiastuti et al. (2015) menunjukkan bahwa penerapan model pembelajaran Guided Inquiry efektif untuk meningkatkan pemahaman konsep peserta didik, hasil penelitian Wardani et al. (2016) menunjukkan bahwa pembelajaran kimia dengan menggunakan modul kimia berbasis Guided Inquiry efektif dalam meningkatkan karakter dan pemahaman konsep peserta didik, hasil penelitian Barthlow and Watson (2014) menunjukkan bahwa dengan menggunakan model pembelajaran Process Oriented Guided Inquiry Learning (POGIL) dapat menghasilkan nilai posttest peserta didik yang lebih baik dari pada model pembelajaran ceramah (tradisional) pada Sekolah Menengah Kimia (School High Chemistry), hasil penelitian Bilgin (2009) 
menunjukkan bahwa dengan menggunakan model pembelajaran Guided Inquiry peserta didik dapat memiliki pemahaman yang lebih baik tentang konsep asam basa dan sikap ilmiah yang lebih positif, hasil penelitian Ezema et al. (2017) menunjukkan bahwa peserta didik yang diajar dengan menggunakan model pembelajaran Guided Inquiry lebih baik hasilnya dari pada peserta didik yang diajar menggunakan metode konvensional pada Sekolah Menengah Biologi (Secondary School Biology).

Berdasarkan permasalahan dan hasil penelitian yang telah diungkapkan di atas, maka penulis bermaksud akan mengembangkan perangkat pembelajaran IPA berbasis guided inquiry pada pokok bahasan "Energi dalam Sistem Kehidupan". Adapun perangkat pembelajaran IPA berbasis guided inquiry yang akan dikembangkan mencakup Rencana Pelaksanaan Pembelajaran (RPP), Lembar Kerja Peserta Didik (LKPD), dan Bahan Ajar Peserta Didik (BAPD).

\section{METODE}

Penelitian ini adalah penelitian pengembangan (Research and Development) yang bertujuan untuk mengembangkan perangkat pembelajaran IPA pada pokok bahasan energi dalam sistem kehidupan berbasis guided inquiry dengan pendekatan saintifik yang terdiri dari Rencana Pelaksanaan Pembelajaran (RPP), Lembar Kerja Peserta Didik (LKPD), dan Bahan Ajar Peserta Didik (BAPD) yang dikembangkan dengan menggunakan model pengembangan 4-D. Penelitian ini dilaksanakan di SMPN 36 Makassar pada kelas VII.1 semester ganjil tahun pelajaran 2018/2019 dengan jumlah peserta didik 28 orang. Pengembangan perangkat pembelajaran IPA pokok bahasan Energi dalam Sistem Kehidupan berbasis guided inquiry menggunakan model Thiagarajan yang dikenal dengan 4-D yaitu define, design, develop, dan disseminate.

Perangkat pembelajaran yang dikembangkan dalam penelitian ini merujuk pada tiga syarat kualitas, yakni valid, praktis, dan efektif. Informasi tentang kevalidan, kepraktisan, dan keefektifan terhadap perangkat pembelajaran yang telah dikembangkan diperoleh melalui instrumeninstrumen penelitian kevalidan, kepraktisan, dan keefektifan. Data yang diperoleh lalu dianalisis menggunakan teknik analisis statistik deskriptif.

Kevalidan menunjukkan tingkat kesahihan atau ketepatan tentang perangkat pembelajaran yang dikembangkan, dan merupakan hasil penilaian dari ahli atau validator melalui kuesioner yang diberikan. Perangkat pembelajaran dikatakan valid apabila penilaian oleh para ahli berada pada kriteria minimal valid. Instrumen dikategorikan reliabel jika diperoleh nilai reliabilitas hitung lebih besar daripada reliabilitas tabel.

Perangkat pembelajaran dikatakan praktis jika memenuhi dua kriteria, yaitu (1) perangkat pembelajaran yang dikembangkan dapat diterapkan menurut penilaian para ahli dan/ atau praktisi; (2) perangkat pembelajaran yang dikembangkan dapat diterapkan secara riil di lapangan melalui pengamatan keterlaksanaan pembelajaran di kelas. Khusus kriteria kedua, hasil pengamatan keterlaksanaan pembelajaran di kelas termasuk dalam kategori minimal baik.

Perangkat pembelajaran dikatakan efektif jika memenuhi dua kriteria, yaitu (1) perangkat yang dikembangkan efektif menurut ahli dan atau praktisi; (2) perangkat yang dikembangkan dapat memberikan hasil yang sesuai dengan indikator keefektifan yaitu: (1) hasil belajar, (2) aktivitas peserta didik, (3) kemampuan guru mengelola pembelajaran, dan (4) respon peserta didik dan guru. Perangkat pembelajaran dikatakan efektif jika memenuhi 3 dari empat indikator di atas, dimana indikator pertama yaitu hasil belajar harus terpenuhi.

\section{HASIL DAN PEMBAHASAN}

\section{Proses Pengembangan Perangkat Pembelajaran IPA Berbasis Guided Inquiry}

Proses pengembangan perangkat pembelajaran IPA berbasis guided inquiry 
ini menggunakan model 4-D dari Thiagarajan yang terdiri dari empat tahap, yang pertama tahap pendefinisian (define) dimana tahap ini yaitu untuk menganalisis kebutuhan dalam belajar. Selanjutnya tahap perancangan (design) yaitu untuk menyiapkan rancangan awal perangkat pembelajaran. Tahap perancangan ini terdiri atas 4 langkah, yaitu: (1) penyusunan tes, tes ini merupakan alat untuk mengukur pencapaian hasil belajar peserta didik, (2) pemilihan media yang sesuai tujuan, untuk menyampaikan materi pembelajaran, (3) pemilihan format untuk menentukan format isi perangkat pembelajaran yang akan digunakan, yaitu format yang sesuai dengan karakteristik dan langkah-langkah pembelajaran guided inquiry, dan (4) rancangan awal.

Tahapan selanjutnya adalah pengembangan (develop) untuk menghasilkan perangkat pembelajaran mencakup Rencana Pelaksanaan Pembelajaran (RPP), Bahan Ajar Peserta Didik (BAPD), dan Lembar Kerja Peserta Didik (LKPD) IPA berbasis guided inquiry yang valid, praktis dan efektif melalui serangkaian proses, yaitu: (1) validasi ahli, (2) simulasi (uji coba terbatas pada peserta didik sebelum diujicobakan dengan peserta didik yang sesungguhnya), dan (3) uji coba terbatas dengan peserta didik yang sesungguhnya. Berdasarkan masukan dari serangkaian proses tersebut dilakukan revisi terhadap perangkat pembelajaran yang dikembangkan.

Tahapan terakhir adalah penyebaran (disseminate) untuk memperoleh saran dan kritikan dari guru-guru sebagai praktisi pendidikan terhadap perangkat pembelajaran agar lebih baik, sehingga dapat dihasilkan perangkat pembelajaran yang dapat digunakan oleh semua guru mata pelajaran terkait di daerah manapun berada. Tahap ini merupakan tahap penggunaan perangkat pembelajaran yang telah dikembangkan pada skala yang lebih luas, misalnya di kelas lain, di sekolah lain, atau oleh guru yang lain. Dalam penelitian ini, perangkat pembelajaran IPA berbasis guided inquiry sebagai draft III selain diujicobakan pada peserta didik kelas VII.1 SMP Negeri 36 Makassar, juga disebarkan dan disosialisasikan secara terbatas kepada 5 orang guru IPA SMP Negeri 36 Makassar. Dari hasil sosialisasi tersebut diperoleh beberapa saran untuk memperbaiki perangkat pembelajaran tersebut.

\section{Kualitas Perangkat Pembelajaran IPA Berbasis Guided Inquiry}

Hasil validasi terhadap Rencana Pelaksanaan Pembelajaran (RPP) IPA berbasis guided inquiry dapat dilihat pada Tabel 1.

Tabel 1. Rekapitulasi Hasil Validasi Ahli terhadap RPP IPA Berbasis Guided Inquiry

\begin{tabular}{clcccc}
\hline No. & \multicolumn{1}{c}{ Aspek yang Dinilai } & V1 & V2 & Rata-rata & Kategori \\
\hline 1 & Rumusan KD dan Indikator & 4,50 & 4,00 & 4,25 & Valid/Tinggi \\
2 & Isi yang Disajikan & 5,00 & 4,00 & 4,50 & Valid/Tinggi \\
3 & Penggunaan Bahasa & 5,00 & 4,00 & 4,50 & Valid/Tinggi \\
4 & Alokasi Waktu & 4,00 & 4,00 & 4,00 & Valid/Tinggi \\
5 5 & 4,25 & 4,00 & 4,13 & Valid/Tinggi \\
& Pendekatan, Metode, dan Teknik & 4,55 & 4,00 & 4,28 & Valid/Tinggi \\
\hline \multicolumn{5}{c}{100} \\
\hline \multicolumn{5}{c}{ Rata-rata Percentage of Agreement $(R)$} \\
\hline
\end{tabular}

Rata-rata penilaian validator terhadap RPP dari aspek rumusan KD dan indikator, isi yang disajikan, penggunaan bahasa, alokasi waktu, serta pendekatan, metode, dan teknik pembelajaran adalah 4,28 dengan kategori valid/tinggi karena berada pada rentang $4 \leq \mathrm{V}_{\mathrm{a}}<5$ dan persentase reliabilitas 1 atau $100 \%$. Hal ini berarti bahwa RPP disusun sesuai dengan prinsip-prinsip pengembangan RPP, dan seluruh komponen 
dalam penyusunan RPP telah tercantum, sehingga RPP ini dapat diterapkan dalam kegiatan pembelajaran. Meskipun demikian, ada beberapa saran dari tim validator yang perlu diperhatikan dalam melakukan revisi terhadap RPP yang dikembangkan agar dapat menghasilkan RPP yang lebih baik. Hasil akhir terhadap revisi Rencana
Pelaksanaan Pembelajaran (RPP) IPA berbasis guided inquiry merupakan perangkat pembelajaran draft II yang digunakan pada uji coba perangkat pembelajaran. Selanjutnya, hasil validasi terhadap Bahan Ajar Peserta Didik (BAPD) IPA berbasis guided inquiry dapat dilihat pada Tabel 2.

Tabel 2. Rekapitulasi Hasil Validasi Ahli terhadap BAPD IPA Berbasis Guided Inquiry

\begin{tabular}{clcccc}
\hline No. & \multicolumn{1}{c}{ Aspek yang Dinilai } & V1 & V2 & Rata-rata & Kategori \\
\hline 1 & Penjabaran Konsep & 5,00 & 4,25 & 4,63 & Valid/Tinggi \\
2 & Bahasa & 5,00 & 4,40 & 4,70 & Valid/Tinggi \\
3 & Konstruksi & 4,33 & 4,00 & 4,17 & Valid/Tinggi \\
4 & Manfaat/Kegunaan BAPD & 5,00 & 4,00 & 4,50 & Valid/Tinggi \\
\hline \multicolumn{2}{c}{ Rata-rata } & 4,83 & 4,16 & 4,50 & Valid/Tinggi \\
\hline \multicolumn{3}{c}{ Rata-rata Percentage of Agreement $(R)$} \\
\hline
\end{tabular}

Rata-rata penilaian validator terhadap BAPD ditinjau dari aspek penjabaran konsep, bahasa, konstruksi, dan manfaat/kegunaan BAPD adalah 4,50 dengan kategori valid/tinggi karena berada pada rentang $4 \leq \mathrm{V}_{\mathrm{a}}<5$ dan persentase reliabilitas 1 atau $100 \%$. Hal ini berarti bahwa BAPD telah disusun berdasarkan pada rasional teoritik yang kuat dan memiliki konsistensi internal, yakni saling berkaitan antar komponen dalam BAPD tersebut dengan perangkat pembelajaran lainnya, sehingga BAPD ini dapat digunakan sebagai bahan ajar dalam kegiatan pembelajaran. Namun demikian berdasarkan saran dan komentar tim validator maka dilakukan revisi kecil untuk penyempurnaan perangkat pembelajaran berupa Bahan Ajar Peserta Didik (BAPD) ini. Hasil akhir revisi BAPD IPA berbasis guided inquiry merupakan perangkat pembelajaran draft II yang digunakan pada uji coba perangkat pembelajaran. Sedangkan hasil validasi terhadap Lembar Kerja Peserta Didik (LKPD) IPA berbasis guided inquiry dapat dilihat pada Tabel 3.

Tabel 3. Rekapitulasi Hasil Validasi Ahli terhadap LKPD IPA Berbasis Guided Inquiry

\begin{tabular}{clcccc}
\hline No. & \multicolumn{1}{c}{ Aspek yang Dinilai } & V1 & V2 & Rata-rata & Kategori \\
\hline 1 & Format LKPD & 5,00 & 4,17 & 4,58 & Valid/Tinggi \\
2 & Bahasa & 5,00 & 4,40 & 4,70 & Valid/Tinggi \\
3 & Isi LKPD & 4,17 & 4,33 & 4,25 & Valid/Tinggi \\
4 & Waktu & 5,00 & 4,00 & 4,50 & Valid/Tinggi \\
5 & Manfaat/Kegunaan BAPD & 4,50 & 4,00 & 4,25 & Valid/Tinggi \\
\hline \multicolumn{2}{r}{ Rata-rata } & 4,73 & 4,18 & 4,46 & Valid/Tinggi \\
\hline \multicolumn{4}{c}{ Rata-rata Percentage of Agreement $(R)$} & \multicolumn{3}{c}{100} & Reliabel \\
\hline
\end{tabular}

Rata-rata penilaian tim validator terhadap LKPD ditinjau dari aspek format LKPD, bahasa, isi LKPD, waktu, dan manfaat/kegunaan LKPD adalah 4,46 dengan kategori valid/tinggi karena berada pada rentang $4 \leq \mathrm{V}_{\mathrm{a}}<5$ dan persentase reliabilitas 1 atau $100 \%$. Hal ini berarti bahwa LKPD telah disusun berdasarkan pada rasional teoritik yang kuat dan memiliki konsistensi internal, yakni saling berkaitan antar komponen dalam LKPD tersebut dengan perangkat pembelajaran 
lainnya, sehingga LKPD ini dapat digunakan dalam kegiatan pembelajaran. Namun demikian berdasarkan saran dan komentar tim validator maka dilakukan revisi kecil untuk LKPD yang dikembangkan. Hasil akhir revisi terhadap Lembar Kerja Peserta Didik (LKPD) IPA berbasis guided inquiry tersebut merupakan perangkat pembelajaran draft II yang digunakan pada uji coba perangkat pembelajaran. Secara umum semua penilaian validator terhadap perangkat pembelajaran yang dikembangkan baik Rencana Pelaksanaan Pembelajaran (RPP), Bahan Ajar Peserta Didik (BAPD), dan Lembar Kerja Peserta Didik (LKPD) IPA berbasis guided inquiry berada pada kategori valid, baik dan dapat digunakan dengan melakukan revisi kecil. Hal ini berarti bahwa perangkat pembelajaran IPA berbasis guided inquiry yang dikembangkan layak untuk diujicobakan setelah dilakukan revisi kecil sebagaimana saran-saran serta petunjuk dari tim validator.

Selain dilakukan validasi terhadap perangkat pembelajaran IPA berbasis guided inquiry tersebut di atas, juga dilakukan validasi terhadap instrumen penelitian yang akan digunakan, yaitu Tes Hasil Belajar
(THB), lembar observasi keterlaksanaan perangkat pembelajaran, lembar angket respon guru, lembar angket respon peserta didik, lembar observasi pengelolaan pembelajaran, dan lembar observasi aktivitas peserta didik. Instrumen penelitian tersebut digunakan untuk mengukur keefektifan dan kepraktisan perangkat pembelajaran.

Keseluruhan komponen Tes Hasil Belajar (THB), lembar observasi keterlaksanaan perangkat pembelajaran, lembar angket respon guru, lembar angket respon peserta didik, lembar observasi pengelolaan pembelajaran, dan lembar observasi aktivitas peserta didik dinilai valid yaitu berada pada $V_{a}=2$ dengan koefisien reliabilitas rata-rata $(\mathrm{R}) \geq 0,75$. Penilaian secara umum oleh para ahli untuk instrumen penelitian ini adalah valid dan layak digunakan dengan revisi/perbaikan.

Penentuan kepraktisan perangkat pembelajaran pada penelitian ini dilihat dari kekonsistenan hasil dua ukuran, yaitu intended $\leftrightarrow$ perceived (IP dari ahli atau praktisi) dan ukuran intended $\leftrightarrow$ operational (IO dari pengamat/observer). Kepraktisan perangkat pembelajaran IPA berbasis guided inquiry dapat dilihat pada Tabel 4.

Tabel 4. Hasil Penilaian Kepraktisan Oleh Ahli terhadap Perangkat Pembelajaran IPA Berbasis Guided Inquiry

\begin{tabular}{clcccc}
\hline No. & \multicolumn{1}{c}{ Aspek yang Dinilai } & V1 & V2 & Rata-rata & Kategori \\
\hline \multirow{2}{*}{1} & Rencana Pelaksanaan Pembelajaran & 4,55 & 4,00 & 4,28 & Valid/Tinggi \\
& (RPP) & 4,83 & 4,16 & 4,50 & Valid/Tinggi \\
2 & Bahan Ajar Peserta Didik (BAPD) & 4,73 & 4,18 & 4,46 & Valid/Tinggi \\
\hline & Lembar Kerja Peserta Didik (LKPD) & 4,71 & 4,11 & 4,41 & Valid/Tinggi \\
\hline \multicolumn{2}{r}{ Rata-rata } & \multicolumn{1}{c}{100} & & Reliabel \\
\hline
\end{tabular}

Pada tabel 4 menunjukkan bahwa kepraktisan perangkat pembelajaran IPA berbasis guided inquiry oleh ahli berada pada nilai rata- rata $\mathrm{IP}=4,41$. Hal ini berarti kepraktisan perangkat pembelajaran berada pada kriteria tinggi yaitu pada $4 \leq$ IP $<5$, dan koefisien reliabilitasnya $100 \%$ berarti kepraktisan perangkat pembelajaran IPA berbasis guided inquiry yang diujicobakan dinilai reliabel. Sedangkan secara empirik, berdasarkan hasil pengamatan yang dilakukan oleh dua observer pada uji coba terhadap keterlaksanaan perangkat pembelajaran dapat dilihat pada Tabel 5.

Tabel 5. Hasil Analisis Pengamatan Keterlaksanaan Perangkat Pembelajaran IPA Berbasis Guided Inquiry 
Nur'aini, Danial, Sugiarti. Pengembangan perangkat pembelajaran....

\begin{tabular}{cccccccc}
\hline No. & \multicolumn{1}{c}{$\begin{array}{c}\text { Aspek yang } \\
\text { Dinilai }\end{array}$} & $\mathbf{1}$ & $\mathbf{2}$ & $\mathbf{3}$ & $\mathbf{4}$ & $\begin{array}{c}\text { Rata- } \\
\text { rata }\end{array}$ & Kategori \\
\cline { 2 - 7 } 1 & Sintaks & 4,25 & 4,58 & 4,33 & 4,67 & 4,46 & Tinggi \\
2 & $\begin{array}{l}\text { Interaksi Sosial } \\
\text { Prinsip Reaksi }\end{array}$ & 4,25 & 4,50 & 4,75 & 4,75 & 4,56 & Tinggi \\
3 & $\begin{array}{l}\text { (RPP, BAPD, } \\
\text { LKPD) }\end{array}$ & 4,67 & 4,75 & 4,83 & 4,83 & 4,77 & Tinggi \\
\hline$\quad$ Rata-rata & 4,39 & 4,61 & 4,64 & 4,75 & 4,60 & Tinggi \\
\hline$\quad$ Kategori & Tinggi & Tinggi & Tinggi & Tinggi & - & - \\
\hline $\begin{array}{c}\text { Rata-rata Percentage of } \\
\text { Agreement }(R)\end{array}$ & 100 & 100 & 100 & 100 & 100 & Reliabel \\
\hline
\end{tabular}

Pada tabel 5 menunjukkan bahwa keterlaksanaan perangkat pembelajaran adalah berada pada nilai rata-rata $\mathrm{IO}=4,60$. Hal ini berarti aspek dan kriteria yang diamati pada keterlaksanaan perangkat pembelajaran IPA berbasis guided inquiry berada pada kriteria keterlaksanaan tinggi yaitu pada $4 \leq \mathrm{IO}<5$, dan koefisien reliabilitasnya $100 \%$ berarti keterlaksanaan perangkat pembelajaran IPA berbasis guided inquiry yang diujicobakan dinilai reliabel.

Berdasarkan hasil analisis tersebut dapat disimpulkan bahwa terdapat kekonsistenan antara hasil penilaian persepsi ahli (intended $\leftrightarrow$ perseived) dengan hasil pengamatan observer terhadap penerapan perangkat pembelajaran IPA berbasis guided inquiry di lapangan (intended $\leftrightarrow$ operational), yaitu sama- sama memberikan hasil penilaian kriteria tinggi, maka perangkat pembelajaran yang dikembangkan tersebut dikatakan praktis untuk digunakan.

Penentuan keefektifan perangkat pembelajaran IPA berbasis guided inquiry pada penelitian ini dilihat dari kekonsistenan hasil dua ukuran, yaitu intended $\leftrightarrow$ eksperiential (IE diperoleh dari penilaian pakar atau praktisi berdasarkan pengalamannya) dan ukuran intended $\leftrightarrow$ attained (IA dari data empirik pencapaian tujuan yang ditetapkan). Berdasarkan hasil analisis pada tabel 4 menunjukkan bahwa keefektifan perangkat pembelajaran IPA berbasis guided inquiry oleh pakar berada pada nilai rata-rata $\mathrm{IE}=4,41$. Hal ini berarti keefektifan perangkat pembelajaran tersebut berada pada kriteria tinggi yaitu pada $4 \leq \mathrm{IE}$ $<5$, dan koefisien reliabilitasnya $100 \%$ berarti keefektifan perangkat pembelajaran IPA berbasis guided inquiry yang diujicobakan dinilai reliabel. Sedangkan secara empirik, berdasarkan hasil pengamatan yang dilakukan oleh dua observer pada uji coba terhadap perangkat pembelajaran IPA berbasis guided inquiry yang dikembangkan terhadap Tes Hasil Belajar (THB), kemampuan guru dalam mengelola pembelajaran, aktivitas peserta didik, respon guru dan peserta didik dapat dilihat pada Tabel 6 .

Tabel 6. Deskripsi Ketuntasan Hasil Belajar Aspek Pengetahuan

\begin{tabular}{cccccc}
\hline Interval & \multirow{2}{*}{ Kategori } & \multicolumn{2}{c}{ Pretest } & \multicolumn{2}{c}{ Posttest } \\
\cline { 3 - 6 } Nilai & & Frekuensi & Persentase & Frekuensi & Persentase \\
\hline $76-100$ & Tuntas & - & - & 23 & $82,14 \%$ \\
$0-75$ & Tidak Tuntas & 28 & $100 \%$ & 5 & $17,86 \%$ \\
\hline
\end{tabular}

Berdasarkan hasil analisis Tes Hasil Belajar (THB) aspek pengetahuan pada tabel 6 terlihat bahwa dari 28 peserta didik yang mengikuti Tes Hasil Belajar aspek pengetahuan sebelum dilakukan pembelajaran IPA berbasis guided inquiry adalah $100 \%$ peserta didik berada pada kategori tidak tuntas. Sedangkan hasil dari Tes Hasil Belajar aspek pengetahuan terhadap peserta didik setelah melalui 
pembelajaran IPA berbasis guided inquiry adalah terdapat $82,14 \%$ peserta didik yang tuntas, dan $17,86 \%$ peserta didik yang tidak tuntas. Hal ini menunjukkan persentase ketuntasan Tes Hasil Belajar (THB) aspek pengetahuan peserta didik memenuhi standar ketuntasan secara klasikal. Pembelajaran dikatakan berhasil secara klasikal jika minimal $80 \%$ peserta didik mencapai nilai minimal 76. Dari hasil analisis Tes Hasil Belajar (THB) aspek pengetahuan menunjukkan adanya peningkatan hasil belajar peserta didik yang berada pada kategori tinggi setelah digunakan perangkat pembelajaran IPA berbasis guided inquiry pada proses pembelajarannya.

Berdasarkan hasil observasi aktivitas peserta didik dari pertemuan pertama hingga pertemuan keempat dalam hal mendengarkan/ memperhatikan penjelasan guru/ teman berada pada interval toleransi Persentase Waktu Ideal (PWI) yang disarankan yaitu $20 \% \leq \mathrm{PWI} \leq 30 \%$ dengan rerata persentase $20,78 \%$. Aktivitas peserta didik dalam hal membaca Bahan Ajar Peserta Didik (BAPD) dan/ atau Lembar Kerja Peserta Didik (LKPD) berada pada interval toleransi Persentase Waktu Ideal (PWI) yang disarankan yaitu $10 \% \leq$ PWI $\leq 20 \%$ dengan rerata persentase $12,40 \%$. Aktivitas peserta didik mencatat penjelasan guru, mencatat dari BAPD atau dari teman, bekerja sama untuk menyelesaikan masalah pada LKPD, dan bekerja sama merangkum pekerjaan kelompok berada pada interval toleransi Persentase Waktu Ideal (PWI) yang disarankan yaitu $25 \% \leq \mathrm{PWI} \leq 35 \%$ dengan rerata persentase $34,53 \%$. Dan aktivitas peserta didik dalam diskusi/ bertanya kepada teman/ guru berada pada interval toleransi Persentase Waktu Ideal yang disarankan yaitu $25 \% \leq \mathrm{PWI} \leq 35 \%$ dengan persentase rerata $30,21 \%$. Serta aktivitas peserta didik yang tidak relevan dengan pembelajaran berada pada interval toleransi Persentase Waktu Ideal (PWI) yang disarankan yaitu $0 \% \leq \mathrm{PWI} \leq 5 \%$ dengan persentase rerata $2,08 \%$.
Secara umum dapat dikemukakan bahwa semua aspek aktivitas peserta didik memenuhi kriteria interval toleransi Persentase Waktu Ideal (PWI) yang disarankan. Sedangkan aktivitas peserta didik yang tidak relevan dengan kegiatan pembelajaran dari pertemuan pertama hingga pertemuan keempat berkurang secara bertahap. Dengan demikian, dapat disimpulkan bahwa aktivitas peserta didik pada pembelajaran dengan menggunakan perangkat pembelajaran IPA berbasis guided inquiry memenuhi kriteria efektif.

Sedangkan rata-rata kemampuan guru dalam mengelola pembelajaran dengan menggunakan perangkat pembelajaran IPA berbasis guided inquiry sebesar 4,66 dan berada pada kategori baik dengan rentang 4 $\leq \mathrm{NKG}<5$ dan berdasarkan perhitungan diperoleh koefisien reliabilitas $100 \%$ atau 1 . Hal ini menunjukkan kemampuan guru dalam mengelola pembelajaran IPA berbasis guided inquiry dinilai reliabel. Dengan demikian dapat disimpulkan bahwa tingkat kemampuan guru dalam mengelola dan menggunakan perangkat pembelajaran IPA berbasis guided inquiry telah memenuhi kriteria efektif.

Hasil analisis respon guru terhadap keefektifan perangkat pembelajaran IPA berbasis guided inquiry berada pada persentase persetujuan rata-rata $95,66 \%$. Hal ini menunjukkan bahwa guru IPA SMP Negeri 36 Makassar memberi respon persetujuan terhadap pembelajaran menggunakan perangkat pembelajaran IPA berbasis guided inquiry lebih besar atau sama dengan $80 \%$ dari jumlah subyek yang diteliti. Dengan demikian dapat disimpulkan bahwa respon guru IPA SMP Negeri 36 Makassar terhadap pembelajaran yang menggunakan perangkat pembelajaran IPA berbasis guided inquiry memenuhi kriteria efektif.

Persentase rata-rata respon peserta didik terhadap pembelajaran yang menggunakan perangkat pembelajaran IPA berbasis guided inquiry sebesar 95,50\%. Hal ini menunjukkan bahwa banyaknya peserta didik yang memberikan respon positif 
terhadap pembelajaran menggunakan perangkat pembelajaran IPA berbasis guided inquiry lebih besar atau sama dengan $80 \%$ dari jumlah subyek yang diteliti. Dengan demikian dapat disimpulkan bahwa respon peserta didik terhadap pembelajaran yang menggunakan perangkat pembelajaran IPA berbasis guided inquiry memenuhi kriteria efektif.

Berdasarkan hasil analisis tersebut di atas diperoleh bahwa keempat indikator yakni hasil dari Tes Hasil Belajar aspek pengetahuan terhadap peserta didik setelah melalui pembelajaran IPA berbasis guided inquiry adalah terdapat $82,14 \%$ peserta didik yang tuntas, dan $17,86 \%$ yang tidak tuntas, semua aspek aktivitas yang diamati memenuhi kriteria interval toleransi Persentase Waktu Ideal yang disarankan, kemampuan guru dalam mengelola pembelajaran IPA berbasis guided inquiry berada pada kategori baik, respon persetujuan guru terhadap pembelajaran yang menggunakan perangkat pembelajaran IPA berbasis guided inquiry $95,66 \%$ dan respon positif peserta didik terhadap pembelajaran yang menggunakan perangkat pembelajaran IPA berbasis guided inquiry 95,50\%. Sehingga dapat disimpulkan bahwa perangkat pembelajaran IPA berbasis guided inquiry yang dikembangkan memenuhi kriteria keefektifan.

Jadi terdapat kekonsistenan antara hasil penilaian persepsi ahli atau praktisi (intended $\leftrightarrow$ perseived) dengan hasil pengamatan observer terhadap penerapan perangkat pembelajaran IPA berbasis guided inquiry di lapangan (intended $\leftrightarrow$ operational). Hasil penilaian persepsi ahli/ praktisi (intended $\leftrightarrow$ perseived) yaitu memberikan hasil penilaian kriteria tinggi. Dan hasil pengamatan observer terhadap empat indikator kriteria keefektifan dalam penerapan perangkat pembelajaran IPA berbasis guided inquiry di lapangan (intended $\leftrightarrow$ operational) semuanya terpenuhi, sehingga dapat disimpulkan bahwa perangkat pembelajaran IPA berbasis guided inquiry yang dikembangkan efektif untuk digunakan.

\section{Spesifikasi Produk Perangkat Pembelajaran yang Dihasilkan}

Rencana Pelaksanaan Pembelajaran (RPP) ini dirancang sebagai pedoman bagi guru dalam melaksanakan kegiatan pembelajaran IPA pada jenjang SMP. Ciri khas RPP hasil rancangan adalah: (1) RPP ini disajikan per pertemuan dan disinkronkan dengan BAPD dan LKPD yang dikembangkan oleh peneliti dan disesuaikan dengan sintaks model pembelajaran guided inquiry, (2) RPP dirancang sedemikian rupa sehingga menampakkan keterkaitan antara materi fisika, biologi, dan kimia, (3) format RPP yang digunakan mengacu pada Permendikbud No. 22 Tahun 2016 tentang Standar Proses Pendidikan Dasar dan Menengah, (4) hasil perancangan Rencana Pelaksanaan Pembelajaran (RPP) terdiri dari 4 kali pertemuan.

Bahan Ajar Peserta Didik (BAPD) IPA berbasis guided inquiry dirancang sebagai literatur untuk membantu peserta didik dalam menyelesaikan permasalahan dalam kegiatan pembelajaran IPA. Ciri khas BAPD hasil rancangan adalah: (1) pada BAPD ini disajikan sejumlah pertanyaan atau topik permasalahan yang memungkinkan peserta didik termotivasi untuk membentuk masyarakat belajar, (2) BAPD ini disajikan per pertemuan dan disinkronkan dengan RPP dan LKPD yang dikembangkan oleh peneliti dan disesuaikan dengan sintaks model pembelajaran guided inquiry, (3) materi BAPD dirancang sedemikian rupa sehingga menampakkan keterkaitan antara materi fisika, biologi, dan kimia, (4) format BAPD yang digunakan mengacu pada Depdiknas (2010) tentang petunjuk teknis pengembangan bahan ajar, dan (5) hasil perancangan BAPD terdiri dari 4 kali pertemuan.

Lembar Kerja Peserta Didik (LKPD) IPA berbasis guided inquiry yang dihasilkan dirancang sebagai lembaran-lembaran berisi tugas untuk peserta didik yang dikerjakan dalam proses pembelajaran IPA. Ciri khas LKPD hasil rancangan adalah: (1) LKPD disajikan per pertemuan dan disinkronkan dengan RPP dan BAPD yang 
dikembangkan oleh peneliti, (2) kegiatan pembelajaran dalam LKPD dirancang sesuai dengan sintaks model pembelajaran guided inquiry, (3) dalam LKPD ini terdapat ruangruang kosong yang disediakan sebagai tempat jawaban bagi peserta didik, (4) LKPD ini dirancang sedemikian rupa sehingga menampakkan keterkaitan antara materi fisika, biologi, dan kimia, (5) format LKPD yang digunakan mengacu pada Depdiknas (2010) tentang petunjuk teknis pengembangan bahan ajar, dan (6) hasil perancangan LKPD terdiri dari 4 kali pertemuan.

\section{SIMPULAN DAN SARAN}

Berdasarkan hasil analisis dan pembahasan hasil penelitian yang telah dilakukan, maka dapat disimpulkan bahwa perangkat pembelajaran yang dikembangkan menggunakan model pengembangan 4-D Thiagarajan yang terdiri dari empat tahap, yaitu tahap pendefinisian (define), perancangan (design), pengembangan (develop), dan penyebaran (disseminate), diperoleh perangkat pembelajaran yang memenuhi kriteria valid, praktis, dan efektif. Nilai rata-rata kevalidan perangkat pembelajaran yang dikembangkan berada pada kriteria valid atau tinggi dan keseluruhan komponen perangkat pembelajaran dinilai reliabel. Terdapat kekonsistenan antara hasil penilaian persepsi ahli dengan hasil pengamatan observer terhadap penerapan perangkat pembelajaran di lapangan, yaitu sama-sama memberikan hasil penilaian kriteria tinggi atau baik, maka perangkat pembelajaran IPA berbasis guided inquiry yang dikembangkan dikatakan praktis. Terdapat kekonsistenan antara hasil penilaian persepsi ahli dengan hasil pengamatan observer terhadap penerapan perangkat pembelajaran di lapangan. Hasil penilaian persepsi ahli yaitu memberikan hasil penilaian kriteria tinggi atau baik. Dan hasil pengamatan observer terhadap empat indikator kriteria keefektifan diperoleh bahwa perangkat pembelajaran IPA berbasis guided inquiry yang dikembangkan efektif untuk digunakan karena empat indikator kriteria keefektifan dalam penerapan perangkat pembelajaran di lapangan semuanya terpenuhi. Keempat indikator tersebut adalah Tes Hasil Belajar, aktivitas peserta didik, kemampuan guru dalam mengelola pembelajaran, serta respon guru dan respon peserta didik terhadap pembelajaran yang menggunakan perangkat pembelajaran IPA berbasis guided inquiry.

\section{DAFTAR RUJUKAN}

Barthlow, M. J., \& Watson, S. B. 2014. The Effectiveness of Process-Oriented Guided Inquiry Learning to Reduce Alternative Conceptions in Secondary Chemistry. School Science and Mathematics, 114(5), 246-255.

Bilgin, I. 2009. The Effects of Guided Inquiry Instruction Incorporating a Cooperative Learning Approach on University Students' Achievement of Acid and Bases Concepts and Attitude toward Guided Inquiry Instruction. Academic Journals, 4(10), 1038-1046.

Departemen Pendidikan Nasional. 2010. Petunjuk Teknis Pengembangan Bahan Ajar SMA. Jakarta: Departemen Pendidikan Nasional.

Ezema, M., Adejoh, M. J., Iji, C. O., Ochu, A. N. 2017. Effect of Guided Inquiry Instructional Method on Secondary School Students' Retention in Biology in Plateau State, Nigeria. Journal of Science, Technology \& Education, 5(2), 131-138.

Kementerian Pendidikan dan Kebudayaan. 2016. Permendikbud Nomor 22 Tahun 2016 tentang Standar Proses Pendidikan Dasar dan Menengah. Jakarta: Kementerian Pendidikan dan Kebudayaan.

Kunandar. 2014. Penilaian Autentik (Penilaian Hasil Belajar Peserta Didik Berdasarkan Kurikulum 2013). Jakarta: RajaGrafindo Persada.

Margiastuti, S. N., Parmin, P., \& Pamelasari, S. D. 2015. Penerapan Model Guided Inquiry terhadap Sikap Ilmiah dan 
Pemahaman Konsep Siswa pada Tema Ekosistem. Unnes Science Education Journal, 4(3), 1041-1048.

Sani, R. A. 2015. Pembelajaran Saintifik untuk Implementasi Kurikulum 2013. Jakarta: Bumi Aksara.

Sudiarman, W., Soegimin, \& Susantini, E. 2015. Pengembangan Perangkat Pembelajaran Fisika Berbasis Inkuiri Terbimbing untuk Melatihkan Keterampilan Proses Sains dan Meningkatkan Hasil Belajar pada Topik Suhu dan Perubahannya. Jurnal Pendidikan Sains Pascasarjana Universitas Negeri Surabaya, 4(2), 658-671.

Suduc, M. A., Bizoi, M., \& Gorghiu, G. 2015. Inquiry Based Science Learning in Primary Education. Procedia-Social and Behavioral Sciences, 205(2015), 474-479.

Sulistyawan, E., Susantini, E., \& Indana, S. 2015. Pengembangan Perangkat Pembelajaran IPA Berbasis Inkuiri Terbimbing untuk Menumbuhkan Minat dan Hasil Belajar Siswa SMPN Satu Atap. Jurnal Pendidikan Sains Pascasarjana Universitas Negeri Surabaya, 5(1), 867-873.

Susanti, R., Supardi, Z. A. I., \& Indana, S. 2016. Pengembangan Perangkat Pembelajaran IPA Model Inkuiri Terbimbing untuk Melatihkan Keterampilan Proses Sains Siswa SMP. Jurnal Pendidikan Sains Pascasarjana Universitas Negeri Surabaya, 6(1), 1255-1264.

Wardani, S., Nurhayati, S., \& Safitri, A. 2016. The Effectiveness of the Guided Inquiry Learning Module Towards Students' Character and Concept Understanding. International Journal of Science and Research (IJSR), 5(6), 1589-1594. 